\title{
FAKTOR-FAKTOR YANG BERHUBUNGAN DENGAN KENAIKAN TEKANAN DARAH PADA PEKERJA BAGIAN STONE CRUSHER DI PT LUTVINDO WIJAYA PERKASA PEKANBARU TAHUN 2015
}

\author{
Dwi Sapta Aryantiningsih
}

STIKes Payung Negeri Pekanbaru

\begin{abstract}
ABSTRAK
Kenaikan tekanan darah adalah apabila adanya kenaikan tekanan darah sistolik $\geq 30 \mathrm{mmHg}$ dan tekanan darah diastolik $\geq 15 \mathrm{mmHg}$. Kenaikan tekanan darah didiagnosa akan menyebabkan penyakit hipertensi (Garnadi, 2012). World Health Organization (WHO) menyatakan bahwa hipertensi merupakan penyebab nomor 1 kematian di dunia. Survei pendahuluan pada pekerja di PT Lutvindo Wijaya Perkasa Pekanbaru sebelum dan sesudah bekerja didapatkan $30 \%$ pekerja mengalami kenaikan tekanan darah sistolik dan 53\% pekerja mengalami kenaikan tekanan darah diastolik setelah bekerja. Tujuan dari penelitian ini adalah untuk memperoleh Faktor-Faktor Yang Berhubungan Dengan Kenaikan Tekanan Darah Pada Pekerja Bagian Stone Cursher Di PT Lutvindo Wijaya Perkasa Pekanbaru Tahun 2015.

Penelitian ini menggunakan jenis penelitian kuantitatif analitik dengan desain cross sectional. Penelitian ini dilakukan 08 Juni - 16 Juni 2015 di PT Lutvindo Wijaya Perkasa Pekanbaru Tahun 2015. Populasi yaitu seluruh pekerja dibagian stone crusher yang berjumlah 35 orang dan seluruh pekerja menjadi objek penelitian dengan menggunakan kuesioner. Analisa yang digunakan adalah analisa univariat dan bivariat.

Hasil penelitian ini menunjukkan proporsi pekerja yang mengalami kenaikan tekanan darah yaitu 54,3\%. Variabel status merokok (POR=10,929; CI 95\%=1,867-63,968), kebisingan (POR=6,250; CI95\%=1,399-27,925) yang berhubungan signifikan dengan kenaikan tekanan darah.

Kesimpulan yaitu status merokok dan kebisingan berhubungan dengan kenaikan tekanan darah. Oleh karena itu disarankan kepada pihak PT Lutvindo Wijaya Perkasa Pekanbaru untuk dapat memberikan earplug kepada pekerja yang terpapar kebisingan serta meminimalisir tingkat kebisingan di tempat kerja dengan melakukan perawatan mesin berkala sehingga mesih terjaga, dan memberikan penyuluhan kepada pekerja mengenai bahaya rokok terhadap kenaikan tekanan darah
\end{abstract}

Kata Kunci $\quad$ : Kenaikan Tekanan Darah, Status Merokok, Kebisingan

\section{PENDAHULUAN}

Menurut Tarwaka \& dkk (2004) di tempat kerja terdapat beberapa faktor yang mempengaruhi lingkungan kerja seperti faktor fisik, faktor kimia, faktor biologi, dan faktor psikologis. Pada umumnya, faktor fisik yang dapat menimbulkan gangguan berupa peningkatan nadi, kontruksi pembuluh darah perifer terutama pada tangan dan kaki, gangguan sensoris, dan tekanan darah (Suma'mur, 2009).

Tekanan darah merupakan kekuatan atau tenaga yang digunakan oleh darah untuk melawan dinding pembuluh arteri dan biasa diukur dalam satuan milimeter air raksa $(\mathrm{mmHg})$. Nilai tekanan darah dinyatakan dalam dua angka, yaitu angka tekanan darah sistolik dan diastolik. Tekanan darah dikatakan optimal jika nilai sistolik sebesar $120 \mathrm{mmHg}$ dan $80 \mathrm{mmHg}$ pada nilai diastolik (Prasetyaningrum, 2014).
Kenaikan tekanan darah adalah apabila adanya kenaikan tekanan darah sistolik $\geq 30$ mmHg dan tekanan darah diastolik $\geq 15 \mathrm{mmHg}$ (Prawirohardjo, 2009). Faktor-faktor yang berhubungan dengan kenaikan tekanan darah yaitu usia, jenis kelamin, kurangnya aktivitas fisik, stres, obesitas, minum alkohol, status merokok, faktor keturunan, kebisingan dan tekanan panas. Kenaikan tekanan darah juga didiagnosa akan menyebabkan penyakit Hipertensi (Garnadi, 2012).

Sementara itu, hasil Riset Kesehatan Dasar (Riskesdas) tahun 2013 menunjukkan prevalensi hipertensi di Indonesia tahun 2008-2012 sebesar $31,7 \%$, pada penduduk berusia 18 tahun ke atas sebesar $25,8 \%$, dan kasus hipertensi yang belum berhasil terdiagnosa juga masih sangat tinggi yaitu $76 \%$. Dari 33 provinsi di Indonesia, Riau merupakan provinsi yang kasus penderita 
hipertensi melebihi rata-rata yaitu sebesar 23\% (Yanti, 2010).

PT Lutvindo Wijaya Perkasa Pekanbaru merupakan perusahaan industri yang bergerak dalam bidang General, Contractor, Developer dan Supplier yang akan menyalurkan atau memasarkan suatu material kontruksi seperti batu, pasir, dan semen. Dalam proses produksi di perusahaan ini terdapat 3 lokasi, diantaranya Asphal Mixing Plant, Batching Plant, dan Stone Crusher. Dari 3 lokasi tersebut 1 diantaranya yaitu bagian Stone Crusher yang merupakan alat berat yang berguna untuk memecahkan bebatuan atau material padat lainnya menjadi ukuran yang lebih kecil.

Data yang diperoleh dari PT Lutvindo Wijaya Perkasa Pekanbaru bahwa pekerja di bagian Stone Crusher yang berumur $>45$ tahun sebanyak 14 orang. Berdasarkan survei pendahuluan di bagian Stone Crusher dengan mengukur kebisingan, suhu lingkungan kerja, serta tekanan darah sebelum dan sesudah bekerja didapatkan hasil ukur kebisingan yaitu 90,8 dB, hasil ukur suhu lingkungan kerja yaitu $32^{\circ} \mathrm{C}$, dan hasil ukur tekanan darah yang dilakukan didapatkan 30\% pekerja mengalami kenaikan tekanan darah sistolik dan 53\% pekerja mengalami kenaikan tekanan darah diastolik setelah bekerja. Berdasarkan survei awal dari hasil observasi pada 15 pekerja didapatkan $93 \%$ pekerja yang merokok.

Penelitian ini bertujuan untuk mengetahui faktor-faktor yang berhubungan dengan kenaikan tekanan darah pada pekerja bagian Stone Crusher di PT Lutvindo Wijaya Perkasa Pekanbaru Tahun 2015.

\section{METODE PENELITIAN}

Penelitian ini merupakan jenis penelitian kuantitatif, desain analitik korelasi dengan menggunakan desain cross sectional. Populasi dalam penelitian ini adalah seluruh pekerja bagian Stone Crusher di PT Lutvindo Wijaya Perkasa Pekanbaru yang berjumlah 35 orang, dalam penelitian ini seluruh populasi dijadikan sampel (total sampling). Alat pengumpulan data yang digunakan dalam penelitian ini berupa kuesioner. Pengolahan datanya secara editing, coding, processing, cleaning, tabulating dan analisa data secara univariat dan bivariate.

\section{HASIL DAN PEMBAHASAN}

\section{Analisis Univariat}

Tabel 1. Distribusi Frekuensi Variabel Pada Pekerja Bagian Stone Crusher di PT Lutvindo Wijaya Perkasa Pekanbaru Tahun 2015

\begin{tabular}{lcl}
\hline Variabel & Jumlah & $\begin{array}{l}\text { Persentase } \\
(\%)\end{array}$ \\
\hline Kenaikan Tekanan Darah & \\
\hline Meningkat & 19 & 54,3 \\
\hline Tidak meningkat & 16 & 45,7 \\
\hline Usia & & \\
\hline$>45$ tahun & 14 & 40,0 \\
\hline$\leq 45$ tahun & 21 & 60,0 \\
\hline Status Merokok & & \\
\hline Merokok & 24 & 68,6 \\
\hline Tidak Merokok & 11 & 31,4 \\
\hline Kebisingan & \\
\hline Bising & 60,0 \\
\hline Tidak bising & 14 & 40,0 \\
\hline Suhu Lingkungan Kerja & \\
\hline Panas & 20 & 57,1 \\
\hline Tidak panas & 15 & 42,9 \\
\hline
\end{tabular}

\section{Analisis Bivariat}

Tabel 2. Hubungan Usia Dengan Kenaikan Tekanan Darah Pada Pekerja Bagian Stone Crusher Di PT Lutvindo Wijaya Perkasa Pekanbaru Tahun 2015

\begin{tabular}{|c|c|c|c|c|c|c|c|c|}
\hline \multirow{3}{*}{ Usia } & \multicolumn{4}{|c|}{ Kenaikan Tekanan Darah } & \multirow{2}{*}{\multicolumn{2}{|c|}{ Total }} & \multirow{3}{*}{$\begin{array}{l}\text { POR } \\
\text { CI 95\% }\end{array}$} & \multirow{3}{*}{ Pvalue } \\
\hline & \multicolumn{2}{|c|}{ Meningkat } & \multicolumn{2}{|c|}{ Tidak Meningkat } & & & & \\
\hline & $\mathbf{N}$ & $\%$ & $\mathbf{N}$ & $\%$ & $\mathbf{N}$ & $\%$ & & \\
\hline$>45$ tahun & 7 & 50,0 & 7 & 50,0 & 14 & 100,0 & \multirow{3}{*}{$\begin{array}{l}0,750(0,193- \\
2,917)\end{array}$} & \multirow{3}{*}{0,945} \\
\hline$\leq 45$ tahun & 12 & 57,1 & 9 & 42,9 & 21 & 100,0 & & \\
\hline Total & 19 & 54,3 & 16 & 45,7 & 35 & 100,0 & & \\
\hline
\end{tabular}


Tabel 3. Hubungan Status Merokok Dengan Kenaikan Tekanan Darah Pada Pekerja Bagian Stone Crusher Di PT Lutvindo Wijaya Perkasa Pekanbaru Tahun 2015

\begin{tabular}{|c|c|c|c|c|c|c|c|c|}
\hline \multirow{3}{*}{$\begin{array}{l}\text { Status } \\
\text { Merokok }\end{array}$} & \multicolumn{4}{|c|}{ Kenaikan Tekanan Darah } & \multirow{2}{*}{\multicolumn{2}{|c|}{ Total }} & \multirow{3}{*}{$\begin{array}{l}\text { POR } \\
\text { CI 95\% }\end{array}$} & \multirow{3}{*}{ Pvalue } \\
\hline & \multicolumn{2}{|c|}{ Meningkat } & \multicolumn{2}{|c|}{ Tidak Meningkat } & & & & \\
\hline & $\mathbf{N}$ & $\%$ & $\mathbf{N}$ & $\%$ & $\mathbf{N}$ & $\%$ & & \\
\hline Merokok & 17 & 70,8 & 7 & 29,2 & 24 & 100,0 & \multirow{3}{*}{$\begin{array}{l}10,929 \\
(1,867- \\
63,968)\end{array}$} & \multirow{3}{*}{0,011} \\
\hline $\begin{array}{l}\text { Tidak } \\
\text { Merokok }\end{array}$ & 2 & 18,2 & 9 & 81,8 & 11 & 100,0 & & \\
\hline Total & 19 & 54,3 & 16 & 45,7 & 35 & $\mathbf{1 0 0 , 0}$ & & \\
\hline
\end{tabular}

Tabel 4. Hubungan Kebisingan Dengan Kenaikan Tekanan Darah Pada Pekerja Bagian Stone Crusher Di PT Lutvindo Wijaya Perkasa Pekanbaru Tahun 2015

\begin{tabular}{|c|c|c|c|c|c|c|c|c|}
\hline \multirow{3}{*}{$\begin{array}{l}\text { Kebisi- } \\
\text { ngan }\end{array}$} & \multicolumn{4}{|c|}{ Kenaikan Tekanan Darah } & \multirow{2}{*}{\multicolumn{2}{|c|}{ Total }} & \multirow{3}{*}{$\begin{array}{l}\text { POR } \\
\text { CI 95\% }\end{array}$} & \multirow{3}{*}{ Pvalue } \\
\hline & \multicolumn{2}{|c|}{ Meningkat } & \multicolumn{2}{|c|}{ Tidak Meningkat } & & & & \\
\hline & $\mathbf{N}$ & $\%$ & $\mathbf{N}$ & $\%$ & $\mathbf{N}$ & $\%$ & & \\
\hline Bising & 15 & 71,4 & 6 & 28,6 & 21 & 100,0 & \multirow{3}{*}{$\begin{array}{l}6,250 \\
(1,399- \\
27,925)\end{array}$} & \multirow{3}{*}{0,032} \\
\hline $\begin{array}{l}\text { Tidak } \\
\text { Bising }\end{array}$ & 4 & 28,6 & 10 & 71,4 & 14 & 100,0 & & \\
\hline Total & 19 & 54,3 & 16 & 45,7 & 35 & 100,0 & & \\
\hline
\end{tabular}

Tabel 5. Hubungan Suhu Lingkungan Kerja Dengan Kenaikan Tekanan Darah Pada Pekerja Bagian Stone Crusher Di PT Lutvindo Wijaya Perkasa Pekanbaru Tahun 2015

\begin{tabular}{|c|c|c|c|c|c|c|c|c|}
\hline \multirow{3}{*}{$\begin{array}{l}\text { Suhu } \\
\text { Lingkungan } \\
\text { Kerja }\end{array}$} & \multicolumn{4}{|c|}{ Kenaikan Tekanan Darah } & \multirow{2}{*}{\multicolumn{2}{|c|}{ Total }} & \multirow{3}{*}{$\begin{array}{c}\text { POR } \\
\text { CI } \\
95 \%\end{array}$} & \multirow{3}{*}{ Pvalue } \\
\hline & \multicolumn{2}{|c|}{ Meningkat } & \multicolumn{2}{|c|}{ Tidak Meningkat } & & & & \\
\hline & $\mathbf{N}$ & $\%$ & $\mathbf{N}$ & $\%$ & $\mathbf{N}$ & $\%$ & & \\
\hline Panas & 11 & 55,0 & 9 & 45,0 & 20 & 100,0 & 1,069 & \\
\hline Tidak Panas & 8 & 53,3 & 7 & 46,7 & 15 & 100,0 & $(0,279-$ & 1,000 \\
\hline Total & 19 & 54,3 & 16 & 45,7 & 35 & 100,0 & 4,099) & \\
\hline
\end{tabular}

\section{Analisis Univariat}

\section{Kenaikan Tekanan Darah}

Dari hasil penelitian yang dilakukan menunjukkan bahwa responden yang mengalami kenaikan tekanan darah meningkat sebanyak 19 orang $(54,3 \%)$ dan yang mengalami kenaikan tekanan darah tidak meningkat sebanyak 16 orang $(45,7 \%)$.

Menurut Beavers (2008), peningkatan tekanan darah akan mempengaruhi homeostatis di dalam tubuh. Apabila sirkulasi darah menjadi tidak memadai lagi, maka akan terjadi gangguan pada sistem transportasi oksigen, karbondioksida, dan hasil-hasil metabolisme lainnya.
Usia

Dari hasil data yang diperoleh, bahwa 14 orang $(40,0 \%)$ yang berusia $>45$ tahun dan 21 orang $(60,0 \%)$ yang berusia $\leq 45$ tahun. Dikarenakan pekerja bagian stone crusher lebih banyak yang berusia $\leq 45$ tahun.

Menurut Garnadi (2012), pertambahan usia akan meningkatkan risiko kenaikan tekanan darah pada seseorang. Kejadian kenaikan tekanan darah lebih sering terjadi pada kelompok lansia (lanjut usia). Risiko kenaikan tekanan darah meningkat seiring dengan bertambahnya usia, terutama pada pria di atas 45 tahun dan wanita di atas 55 tahun. 


\section{Status Merokok}

Dari hasil data yang diperoleh, bahwa 24 orang $(68,6 \%)$ yang merokok dan 11 orang $(31,4 \%)$ yang tidak merokok. Dikarenakan pekerja bagian stone crusher banyak yang merokok 1 sampai 20 batang dalam sehari.

Menurut Hadi (2014), zat-zat kimia beracun yang dihisap melalui rokok, masuk ke dalam aliran darah dan merusak lapisan endotel pembuluh darah arteri, mengakibatkan proses arterosklerosis, dan kenaikan tekanan darah. Setelah merokok 2 batang saja maka baik tekanan darah sistolik maupun diastolik akan meningkat $10 \mathrm{mmHg}$.

\section{Kebisingan}

Dari hasil data kebisingan yang ada di tempat kerja sebanyak 21 tempat $(60,0 \%)$ yang bising dan 14 tempat $(40,0 \%)$ yang tidak bising. Dikarenakan bagian stone crusher sudah melebihi nilai ambang batas yang sudah ditetapkan yaitu $85 \mathrm{~dB}$ dan tidak memakai alat pelindung telinga.

Menurut Suma'mur (2014), kebisingan adalah semua suara yang tidak dikehendaki yang bersumber dari alat-alat proses produksi dan alat-alat kerja yang pada tingkat tertentu dapat menimbulkan kesehatan dengan intensitas kebisingan rata-rata tidak boleh lebih dari $85 \mathrm{~dB}$ selama 8 jam sehari dan 5 hari kerja seminggu atau 40 jam seminggu.

\section{Suhu Lingkungan Kerja}

Dari hasil data, suhu di tempat kerja ada 20 tempat $(57,1 \%)$ yang panas dan 15 tempat $(42,9 \%)$ yang tidak panas. Dikarenakan pekerja bagian stone crusher sudah memakai alat pelindung diri khususnya helm.

Menurut Suma'mur (2009), pada lingkungan kerja panas, tubuh mengatur suhunya dengan penguapan keringat yang dipercepat dengan pelebaran pembuluh darah yang disertai meningkatnya denyut nadi dan tekanan darah, sehingga kardiovaskuler bertambah.

\section{Analisis Bivariat}

\section{Hubungan Antara Usia Dengan Kenaikan Tekanan Darah}

Berdasarkan hasil penelitian yang didapat bahwa sebanyak 7 orang $(50,0 \%)$ mengalami kenaikan tekanan darah meningkat dengan usia > 45 tahun, sedangkan sebanyak 12 orang $(57,1 \%)$ mengalami kenaikan tekanan darah meningkat dengan usia $\leq 45$ tahun. Hasil penelitian menunjukkan Pvalue sebesar 0,945 berarti > 0,05 yaitu tidak adanya hubungan yang signifikan antara usia dengan kenaikan tekanan darah.

Menurut Hadi (2014), bertambahnya usia menyebabkan kelenturan atau elastisitas pembuluh darah berkurang. Ketika denyut jantung meningkat dikarenakan sistem saraf yang dirangsang oleh kebisingan, maka pembuluh darah kurang bisa melebar dikarenakan berkurangnya elastisitasnya, sehingga kenaikan tekanan darah akan lebih tinggi.. Semakin tua usia seseorang maka tekanan sistol semakin tinggi. Tekanan darah sistolik akan naik terus perlahan-lahan seiring dengan bertambahnya usia, dan akan naik tajam setelah usia 40 tahun, sedangkan tekanan darah diastolik akan tetap naik perlahan-lahan sampai usia 60 tahun kemudian cenderung menurun setelah itu. Menurut peneliti, pekerja mengalami kenaikan tekanan darah dikarenakan adanya faktor-faktor lain yang mempengaruhinya.

\section{Hubungan Antara Status Merokok Dengan Kenaikan Tekanan Darah}

Berdasarkan hasil penelitian yang diperoleh bahwa sebanyak 17 orang $(70,8 \%)$ mengalami kenaikan tekanan darah meningkat dengan status yang merokok. Hasil penelitian menunjukkan Pvalue sebesar 0,011 berarti $<0,05$ yaitu adanya hubungan yang signifikan antara status merokok dengan kenaikan tekanan darah. Nilai POR = 10,929 artinya pekerja yang merokok berisiko 11 kali lebih tinggi mengalami kenaikan tekanan darah dari pada pekerja yang tidak merokok. Di dalam rokok mengandung beberapa zat berbahaya bagi tubuh (Aditama, 2002). 
Rokok yang mengandung nikotin sebagai penyebab ketagihan yang akan merangsang jantung, saraf, otak, dan organ tubuh lainnya bekerja tidak normal. Peningkatan sekresi kelenjar adrenalin serta nikotin yang terkandung pada rokok akan menyempitkan pembuluh darah sehingga terjadi kenaikan tekanan darah (Sianturi, 2004).

Berdasarkan penelitian Hadi (2014), bahwa pekerja perokok yang mengalami peningkatan tekanan darah sistol sebanyak 24 pekerja (77.4\%) dengan Pvalue 0,01 yang artinya ada hubungan yang signifikan antara status merokok dengan kenaikan tekanan darah.

Oleh karena itu diharapkan perusahaan untuk membuat sanksi kepada pekerja yang merokok dan membuat program kesehtan untuk pekerja seperti dilakukannya pemeriksaan kesehatan menyeluruh secara berkala.

\section{Hubungan Antara Kebisingan Dengan Kenaikan Tekanan Darah}

Berdasarkan hasil penelitian yang diperoleh bahwa sebanyak 15 orang $(71,4 \%)$ mengalami kenaikan tekanan darah meningkat akibat bising yang ditimbulkan di tempat kerja, sedangkan sebanyak 4 orang $(28,6 \%)$ mengalami kenaikan tekanan darah meningkat yang tidak bising di tempat kerja. Hasil penelitian menunjukkan Pvalue $=0,032$ berarti $<0,05$ yaitu ada hubungan yang signifikan antara kebisingan dengan kenaikan tekanan darah. Nilai POR = 6,250 artinya pekerja yang mengalami bising lebih beresiko 6 kali lebih tinggi mengalami kenaikan tekanan darah dari pada pekerja yang tidak mengalami bising.

Sumber kebisingan yang ada di PT Lutvindo Wijaya Perkasa Pekanbaru berasal dari suatu proses yang mengalami benturan atau getaran yang diakibatkan dari aktifitas peralatan. Sumber kebisingan tersebut berasal dari mesin stone crusher. Nilai ambang batas kebisingan yang diperbolehkan berdasarkan Keputusan Menteri Tenaga Kerja No. 51/Men/1999 tentang kebisingan adalah sebesar $85 \mathrm{~dB}$ untuk pemaparan 8 jam sehari.

\section{Hubungan Antara Suhu Lingkungan Kerja Dengan Kenaikan Tekanan Darah}

Berdasarkan hasil penelitian yang diperoleh bahwa sebanyak 11 orang $(55,0 \%)$ mengalami kenaikan tekanan darah meningkat akibat suhu lingkungan kerjanya panas, sedangkan sebanyak 8 orang $(53,3 \%)$ mengalami kenaikan tekanan darah meningkat yang suhu lingkungan kerjanya tidak panas. Hasil penelitian menunjukkan Pvalue $=1.000$ berarti $>0,05$ yaitu tidak adanya hubungan yang signifikan antara suhu lingkungan kerja dengan kenaikan tekanan darah.

Menurut Yani (2009), suhu lingkungan kerja adalah ukuran energi rata-rata dari pergerakan molekul-molekul. Dengan di terapkannya penggunaan alat pelindung diri khususnya helm pada pekerja bagian stone crusher di PT Lutvindo Wijaya Perkasa Pekanbaru maka dampak dari suhu lingkungan kerja dapat dikurangi.

Menurut peneliti, tidak adanya hubungan pada variabel ini dikarenakan hasil pengukuran suhu rata-ratanya $29,8^{\circ} \mathrm{C}$ yang masih dapat ditoleransi oleh tubuh karyawan dengan pemakaian helm, sehingga pada level tertentu kenaikan tekanan darah tidak secara langsung, namun apabila hal ini dibiarkan dalam jangka waktu yang panjang dapat berisiko menurunkan produktivitas pekerja, menurunkan konsentrasi pekerja, dan mengakibatkan kenaikan tekanan darah sehingga kecelakaan karena kerja dapat terjadi.

\section{KESIMPULAN DAN SARAN Kesimpulan}

1. Proporsi pekerja yang mengalami kenaikan tekanan darah $54,3 \%$.

2. Adanya hubungan antara status merokok dengan kenaikan tekanan darah dengan hasil Pvalue $=0,011 ;$ POR $=10,929 ;$ CI 95\%= (1,867-63,968).

3. Adanya hubungan antara kebisingan dengan kenaikan tekanan darah dengan hasil Pvalue $=0,032 ; \mathrm{POR}=6,250 ; \mathrm{CI} 95 \%=(1,399$ 27,925). 
Saran

Bagi PT Lutvindo Wijaya Perkasa Pekanbaru

Disarankan agar pihak PT Lutvindo Wijaya Perkasa Pekanbaru dapat memberikan earplug kepada pekerja yang terpapar kebisingan serta meminimalisir tingkat kebisingan di tempat kerja dengan melakukan perawatan mesin berkala sehingga mesin terjaga, dan memberikan penyuluhan kepada pekerja mengenai bahaya rokok terhadap kenaikan tekanan darah.

\section{DAFTAR PUSTAKA}

Aditama. (2000). Hipertensi. Jakarta: EGC

Anizar. (2009). Teknik Keselamatan dan Kesehatan Kerja di Industri. Yogyakarta: Graha Ilmu.

Beavers. (2008). Tekanan Darah. Jakarta: Dian Rakyat.

Garnadi, Y. (2012). Hidup Nyaman dengan Hipertensi. Jakarta: PT Agro Media Pustaka.

Hadi, S. (2014). Faktor-Faktor Yang Mempengaruhi Kenaikan Tekanan Darah Pada Pekerja Yang Terpajan
Kebisingan

Jakarta:

repository.uinjkt.ac.id.

Kepmenaker. (1999). Patent No. 51/MEN/1999 tentang Nilai Ambang Batas Faktor Fisika di Tempat Kerja. Jakarta.

Prasetyaningrum, Y. I. (2014). Hipertensi Bukan Untuk Ditakuti. Jakarta:

FMedia.Riyanto, A. (2011). Aplikasi Metodologi Penelitian Kesehatan. Yogyakarta: Nuha Medika.

Santoso. (2004). Manajemen Keselamatan dan Kesehatan Kerja. Jakarta: Prestasi Pustaka.

Suma'mur. (2014). Higiene Perusahaan dan Kesehatan Kerja (Hiperkes). Jakarta: IKAPI.

Yanti, Y. (2010). Hubungan Penyakit Koroner dengan Tingkat Hipertensi di RSUP H. Adam Malik. Medan: repository. usu .ac.id. 